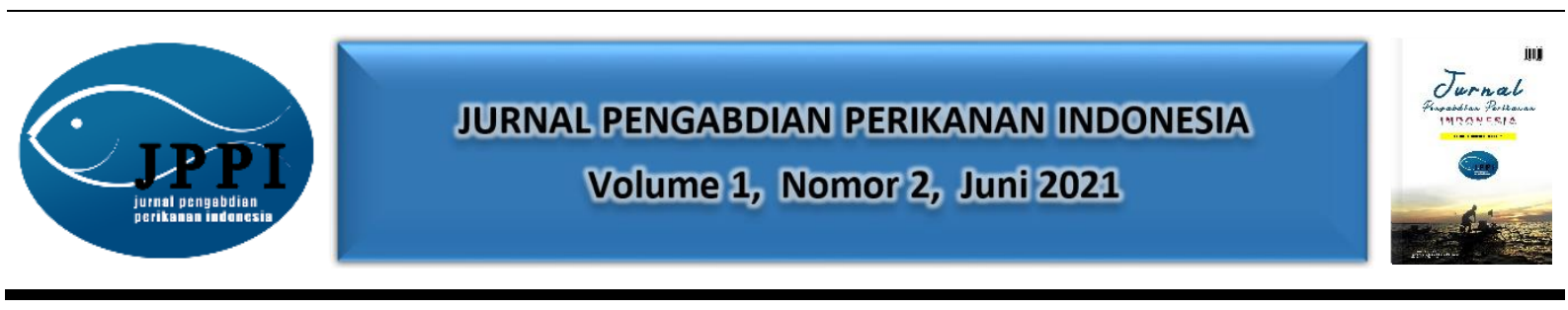

\title{
PEMBERDAYAAN MASYARAKAT KELOMPOK PEMBUDIDAYA IKAN "SUKSES MAJU BERSAMA" MELALUI PRODUKSI PAKAN IKAN MANDIRI DAN MANAJEMEN KUALITAS AIR DI KARANGBESUKI KECAMATAN SUKUN KOTA MALANG
}

\author{
Ganjar Adhywirawan Sutarjo, Hany Handajani \\ Program Studi Akuakultur, Universitas Muhammadiyah Malang \\ Jalan Raya Tlogomas 246, Kota Malang, Provinsi Jawa Timur
}

Alamat korespondensi : ganjar@umm.ac.id

(Tanggal Submission: 10 Juni 2021, Tanggal Accepted : 29 Juni 2021)

\begin{abstract}
Keyword: Abstrak :
Pakan Ikan Kelompok pembudidaya ikan "Sukses Maju Bersama" terletak di kelurahan Mandiri, Karangbesuki Kecamatan Sukun Kota Malang, terbentuk pada tahun 2016. Kendala Manajeme yang dihadapi dalam pengembangan usaha kelompok ini adalah belum diterapkannya $n$ Kualitas manajemen budidaya ikan secara baik. Semakin meningkatnya harga pakan ikan Air, dan buatan pabrik dan pengelolaan kualitas air yang masih belum tepat. Tujuan dari $C B I B$. pelaksanaan kegiatan pengabdian ini adalah untuk meningkatkan pengetahuan dan ketrampilan mitra terkait penerapan standar cara budidaya ikan yang baik (CBIB), produksi pakan ikan mandiri berbasis bahan baku lokal, dan penerapan pengelolaan kualitas air. Kegiatan PPMI ini, menggunakan metode pelatihan dan pendampingan manajemen atau cara budidaya ikan yang baik, kegiatan dilaksanakan selama satu tahun. Hasil yang diperoleh dari program pengabdian yaitu mitra mampu meningkatkan sistem budidaya ikan secara secara intensif melalui penerapan CBIB, mitra mampu memproduksi pakan ikan mandiri berbasis bahan baku lokal diwilayah mitra diantaranya melalui pemanfaatan limbah ampas tahu, dan silase sebagai bahan pakan, serta mitra dapat menerapkan teknik pengelolaan atau manajemen kualitas air melalui penerapan probiotik. Berdasarkan evaluasi bersama, alih teknologi dapat diterima secara baik oleh mitra dan mampu meningkatkan kapasitas produksi budidaya ikan di Kelompok pembudidaya ikan "Sukses Maju Bersama" Sukun Kota Malang.
\end{abstract}

Panduan Sitasi (APPA $7^{\text {th }}$ edition) :

Sutarjo, G.A., \& Handajani, H. (2021). Pemberdayaan Masyarakat Kelompok Pembudidaya Ikan "Sukses Maju Bersama" Melalui Produksi Pakan Ikan Mandiri Dan Manajemen Kualitas Air Di Karangbesuki Kecamatan Sukun Kota Malang. Jurnal Pengabdian Perikanan Indonesia, 1 (2), 157-164. http://doi.org/ 10.29303/jppi.v1i2.114 


\section{PENDAHULUAN}

Kelompok pembudidaya ikan (Pokdakan) merupakan suatu wadah organisasi masyarakat pembudidaya ikan yang terbentuk dan tumbuh atas dasar adanya kepentingan bersama dengan rasa saling percaya, keserasian dan keakraban untuk bekerjasama dalam rangka memanfaatkan sumberdaya alam, mengembangkan usaha, dana, untuk meningkatkan kesejahteraan anggotanya. Salah satu kelompok pembudidaya ikan yang terus berupaya mengembangkan kegiatan budidaya ikan di Kecamatan Sukun Kota Malang adalah kelompok pembudidaya ikan "Sukses Maju Bersama". Terbentuk pada tahun 2016 yang beranggotakan 10 pembudidaya ikan, dengan rata-rata kepemilikan kolam budidaya ikan sebanyak 4-6 petak kolam baik permanen maupun berbahan terpal. Sistem budidaya yang saat ini dilakukan adalah sistem budidaya ikan semi intensif dengan komoditas ikan yang dikembangkan adalah ikan lele, dan ikan nila.

Kendala yang hadapi oleh kelompok pembudidaya ikan Sukses maju bersama adalah Kelompok pembudidaya ikan belum menerapkan manajemen budidaya ikan secara baik, semakin meningkatnya harga pakan ikan buatan pabrik yang mencapai Rp. 11.500/kg, berdampak pada meningkatnya biaya produksi ikan dan belum adanya alih teknologi produksi pakan ikan mandiri berbasis fermentasi dan silase, dan pengelolaan kualitas air yang masih belum tepat, khususnya dalam penggunaan probiotik, dan antibiotik untuk kesehatan ikan.

Kondisi mitra tersebut, perlu mendapatkan perhatian dan solusi dari berbagai pihak salah satunya dari Jurusan Perikanan Fakultas Pertanian Peternakan Universitas Muhammadiyah Malang melalui inovasi teknologi tepat guna yang dapat merubah pola pikir dan wawasan pembudidaya ikan sekaligus menjadi peluang usaha bersama.

Tujuan dari pelaksanaan Program Masyarakat Internal yang dilakukan oleh Tim Perikanan Universitas Muhammadiyah Malang adalah untuk meningkatkan pengetahuan dan ketrampilan mitra terkait penerapan standar cara budidaya ikan yang baik (CBIB), meningkatkan pengetahuan dan ketrampilan mitra dalam produksi pakan ikan mandiri berbasis bahan baku lokal diantaranya adalah ampas tahu, silase ikan, bekatul, dan limbah roti dan meningkatkan pengetahuan dan ketrampilan dalam penerapan pengelolaan kualitas air melalui penggunaan antibiotik herbal dan pemberian probiotik ramah lingkungan.

Manfaat dari pelaksanaan Program Pengabdian Masyarakat Internal yang dilakukan oleh Tim Perikanan UMM di kelompok pembudidaya ikan "Sukses Maju Bersama" Kelurahan Karang besuki Kecamatan Sukun Kota Malang adalah berikut yaitu mitra program dapat menerapkan model budidaya ikan yang baik (CBIB) pada ikan lele, nila, dan koi dalam kolam terpal, mitra memahami kebutuhan dan fungsi prasarana dan sarana produksi budidaya, mitra mampu menerapkan teknik produksi pakan ikan mandiri, dan mampu menerapkan manajemen kualitas air melalui penggunaan probiotik ramah lingkungan dan obat antibiotik herbal sebagai upaya menjaga kesehatan ikan, sehingga melalui kegiatan ini dapat 
meningatakan kapasitas produksi dan mampu memberi manfaat ekonomi bagi kesejahteraan pembudidaya ikan.

\section{METODE PELAKSANAAN}

Metode yang digunakan dalam pelaksanaan program pengabdian masyarakat internal adalah pelatihan dan pendampingan melalui beberapa tahapan kegiatan sebagai berikut:

a) Pelatihan dan pendampingan manajemen budidaya ikan dengan menerapkan standar cara budidaya ikan yang baik (CBIB) yang berpedoman pada petunjuk pelaksanaan sertifikasi cara budidaya ikan yang baik yang ditetapkan oleh kementerian kelautan dan perikanan. (DJPB, 2017).

b) Pelatihan dan pendampingan Produksi pakan ikan mandiri berbasis pada potensi bahan baku pakan diwilayah mitra yaitu melalui pemanfaatan limbah ampas tahu, bekatul, tepung bungkil kedelai, limbah roti, dan silase ikan;

c) Pelatihan dan pendampingan teknik pengelolaan kualitas air dan kesehatan ikan secara terpadu melalui konsep Zero Water Sistem;

d) Melakukan evaluasi bersama mitra terkait keberhasilan dan keberlanjutan program.

\section{HASIL KEGIATAN}

Program Pengabdian Masyarakat Internal (PPMI) dilaksanakan selama delapan bulan di Kelompok Pembudidaya Ikan "Sukses Maju Bersama” Kelurahan Karang Besuki Kecamatan Sukun Kota Malang yang diterapkan melalui kegiatan pelatihan dan pendampingan penguatan kelompok melalui produksi pakan ikan mandiri dan manajemen kualitas air.

Adapun hasil dari kegiatan pengabdian masyarakat yang dilakukan bersama Tim Dosen Perikanan Universitas Muhammadiyah Malang dan mitra program kelompok pembudidaya ikan "Sukses Maju Bersama" adalah sebagai berikut:

\section{Pelatihan Produksi Pakan Ikan Mandiri dan Manajemen Kualitas Air}

Kegiatan Pelatihan ini, memiliki beberapa tujuan yaitu untuk meningatkan pengetahuan dan ketrampilan kepada mitra program terkait tahapan dalam produksi pakan ikan mandiri yang berbasis pada bahan baku lokal. Gambar 1 berikut ini menunjukan aktivitas dalam kegiatan pelatihan, kegiatan dilakukan dengan memperhatikan dan menerapkan protokol kesehatan. 


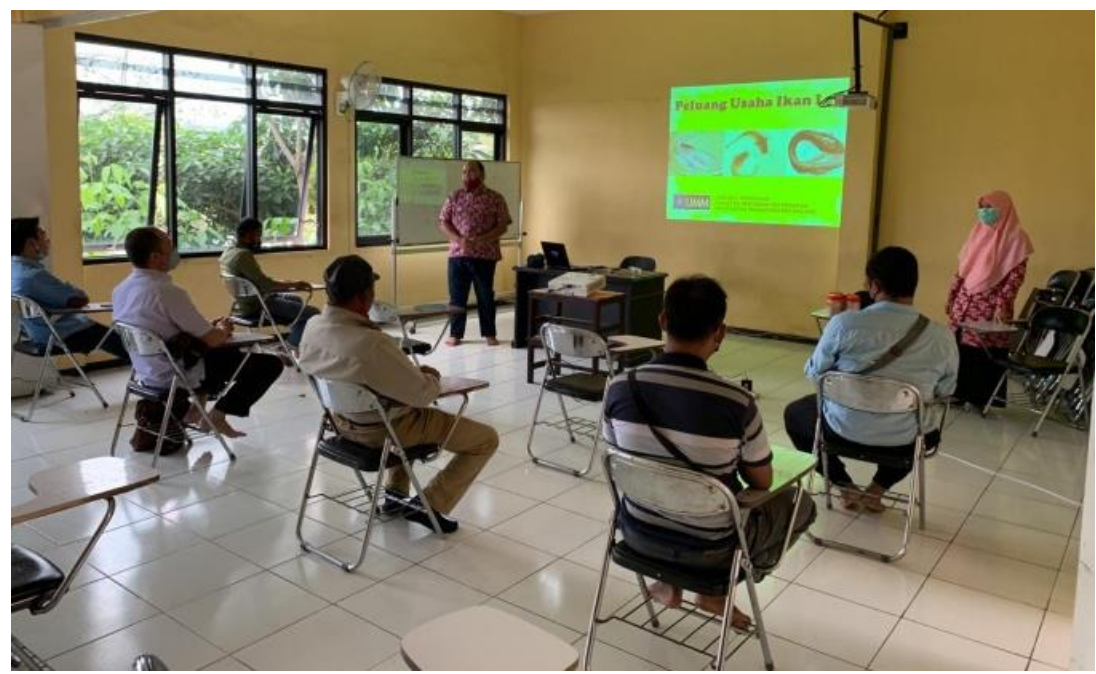

Gambar 1. Pelatihan produksi pakan ikan mandiri dan manajemen kualitas air

Tujuan selanjutnya adalah untuk memberi informasi dasar terkait manajemen kualitas air melalui tahapan kegiatan yaitu penggunaan probiotik dalam media air budidaya ikan, dan monitoring serta pengukuran kualitas air secara kontinyu untuk mencegah terjadinya serangan penyakit selama budidaya ikan yang dilakukan oleh mitra program

\section{Pendampingan Produksi Pakan Ikan Mandiri}

Hasil dari pelaksanaan kegiatan produksi pakan ikan mandiri. Mitra program mampu memenuhi kebutuhan pakan ikan sebanyak $50 \%$ melalui produksi pakan ikan mandiri berbasis bahan baku lokal, untuk produksi $1 \mathrm{~kg}$ pakan ikan mandiri dapat diproduksi dengan biaya sebesar Rp. 7.000 dan dapat dipasarkan dengan harga Rp. 9.000 per kg. Berikut disajikan gambaran kegiatan pendampingan produksi pakan ikan mandiri.

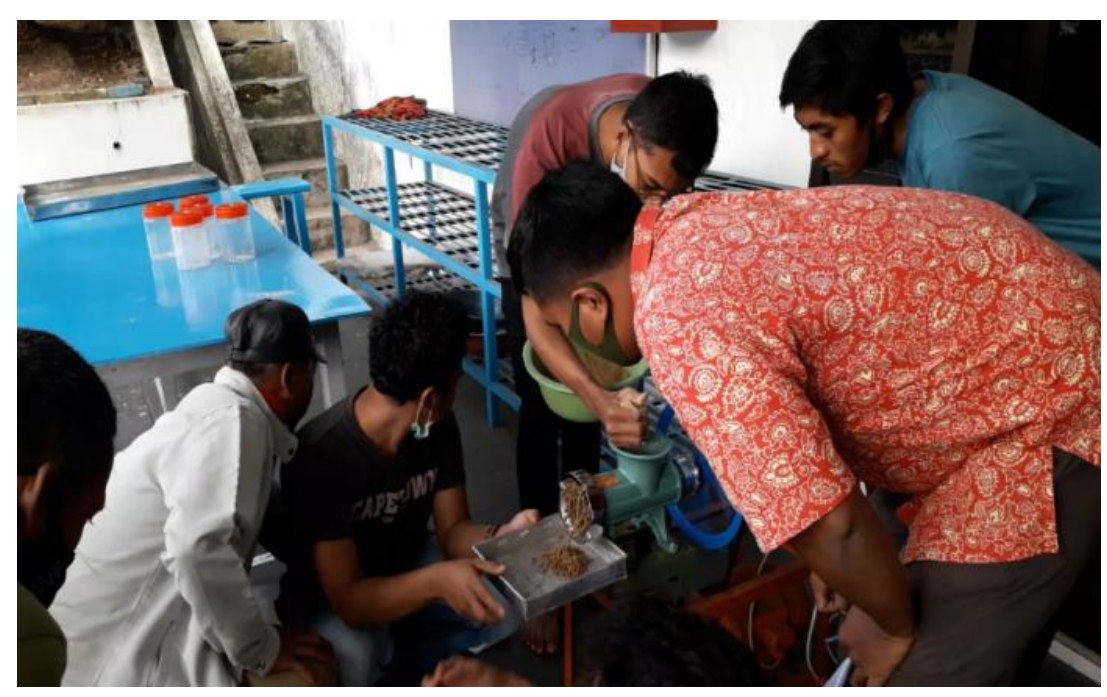

Gambar 2. Pembuatan pakan ikan mandiri 


\section{Pendampingan Manajemen Kualitas Air}

Kegiatan ini menitik beratkan pada pengelolan kualitas air dan penerapan probiotik dalam pakan dan media budidaya ikan. Menurut Sutarjo, dan Warkoyo (2019) menyatakan bahwa manajemen atau pengelolaan kualitas air memegang peranan penting dalam kegiatan budidaya ikan, yang kegiatan meliputi pengontrolan kolam terpal, pemasangan instalasi aerasi, serta pengukuran kualitas air dengan menggunakan alat thermometer suhu air, oxymeter untuk mengukur kandungan oksigen terlarut dalam air, dan $\mathrm{pH}$ test untuk mengukur kadar $\mathrm{pH}$ air. Langkah-langkah dalam pengelolaan kualitas air dikelompok pembudidaya ikan "Sukses Maju Bersama" dilakukan secara berkelanjutan selama kegiatan berlangsung sebagai langkah pencegahan timbulnya serangan penyakit baik yang disebakan oleh jamur, bakteri, dan virus. Adapun tahapan dalam kegiatan pendampingan manajemen kualitas air pada kelompok pembudidaya ikan "Sukses maju bersama" meliputi tahapan kegiatan sebagai berikut yaitu: Tahap 1. Proses penyaringan, dan pengendapan air yang berasal dari sumber air irigasi teknologi yang diterapkan adalah sistem resirkulasi. Langkah ini sangat penting dilakukan mengingat penggunaan sumber air tidak hanya untuk kegiatan budidaya perikanan namun juga dimanfaatkan untuk kegiatan pertanian, dan peternakan. Sehingga potensi masuknya bahan pencemar kedalam kegiatan budidaya dapat dikurangi; Tahap 2. Penerapan probiotik berbasis herbal diantaranya melalui perbanyakan probiotik dengan memanfaatkan bahan yaitu molase atau tetes tebu, temu lawak, kunyit, dan susu sapi murni, langkah pembutan probiotik dilakukan oleh mitra dengan tujuan untuk mengurangi biaya pengadaan probiotik dan untuk menjaga agar kualitas air tetap baik digunakan selama budidaya ikan; Tahap 3. Pengukuran dan monitoring kualitas air meliputi suhu dengan mengunakan termometer air, $\mathrm{pH}$ dengan menggunakan kertas $\mathrm{pH}$ Lakmus, dan kadar ammonia dan nitrat menggunakan alat ukur ammonia dan nitrat kit. Proses pengukuran dilakukan 2 kali pada pagi hari dan sore hari. Tujuan untuk memonitoring mutu air budidaya sehingga baik bagi pertumbuhan dan kelulushidupan ikan selama kegiatan budidaya berlangsung; Tahap 4. Monitoring pertumbuhan dan kesehatan ikan. Hal ini, dilakukan agar mitra mampu melakukan pengukuran pertumbuhan dan kelulusan hidupan serta kesehatan ikan sehingga waktu produksi budidaya dapat tercapai. Gambar 3 berikut menyajikan kegiatan pendampingan kualitas air yang dilakukan. 


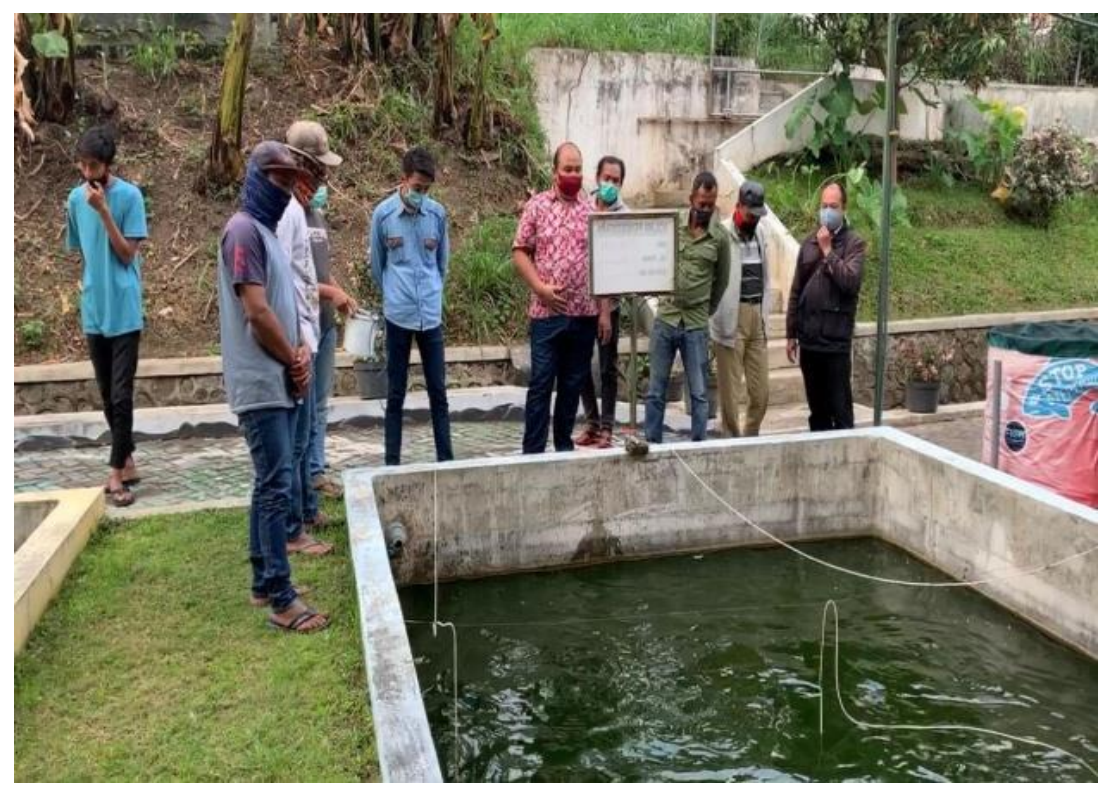

Gambar 3. Pengelolaan Kualitas air dan Kesehatan Ikan

\section{Pendampingan Manajemen Budidaya Ikan Air Tawar}

Pendampingan manajemen budidaya ikan air tawar dilakukan melalui tahap pemenuhan kebutuhan sarana dan prasarana budidaya, konstruksi kolam yang digunakan dalam pengembangan usaha dalam bentuk kolam terpal bundar, mitra juga memperoleh cara pemberian pakan sesuai kebutuhan pertumbuhan dan kelulushidupan ikan, cara pengelolaan kualitas air, kesehatan ikan, dan proses panen serta teknik penanganan ikan hasil budidaya agar kualitas ikan lebih terjaga.

Kegiatan pendampingan dilakukan dalam satu model siklus budidaya ikan lele selama 4 bulan. Dalam proses produksi ikan mitra juga memperoleh teknik perbanyakan probiotik. Menurut Ganjar dan Warkoyo (2019), langkah-langkah dalam teknik perbanyakan probiotik adalah sebagai berikut yaitu melakukan identifikasi bahan baku pembuatan probiotik yang terdapat di wilayah mitra, adapun bahan baku yang dapat digunakan adalah jahe merah, kunyit, buah mengkudu, susu sapi segar, dan tetes tebu atau molase, selanjutnya menyusun formulasi bahan perbanyakan probiotik, proses produksi dan pengemasan.

\section{Evaluasi Pelaksanaan PPMI}

Evaluasi pelaksanaan program dilakukan oleh Tim bersama mitra, hal ini dilakukan untuk mengukur tingkat keberhasilan dan keberlanjutan alih teknologi kepada mitra program. Berikut disajikan grafik produksi ikan (lele dan nila) dikelompok pembudidaya ikan Sukses Maju Bersama. 


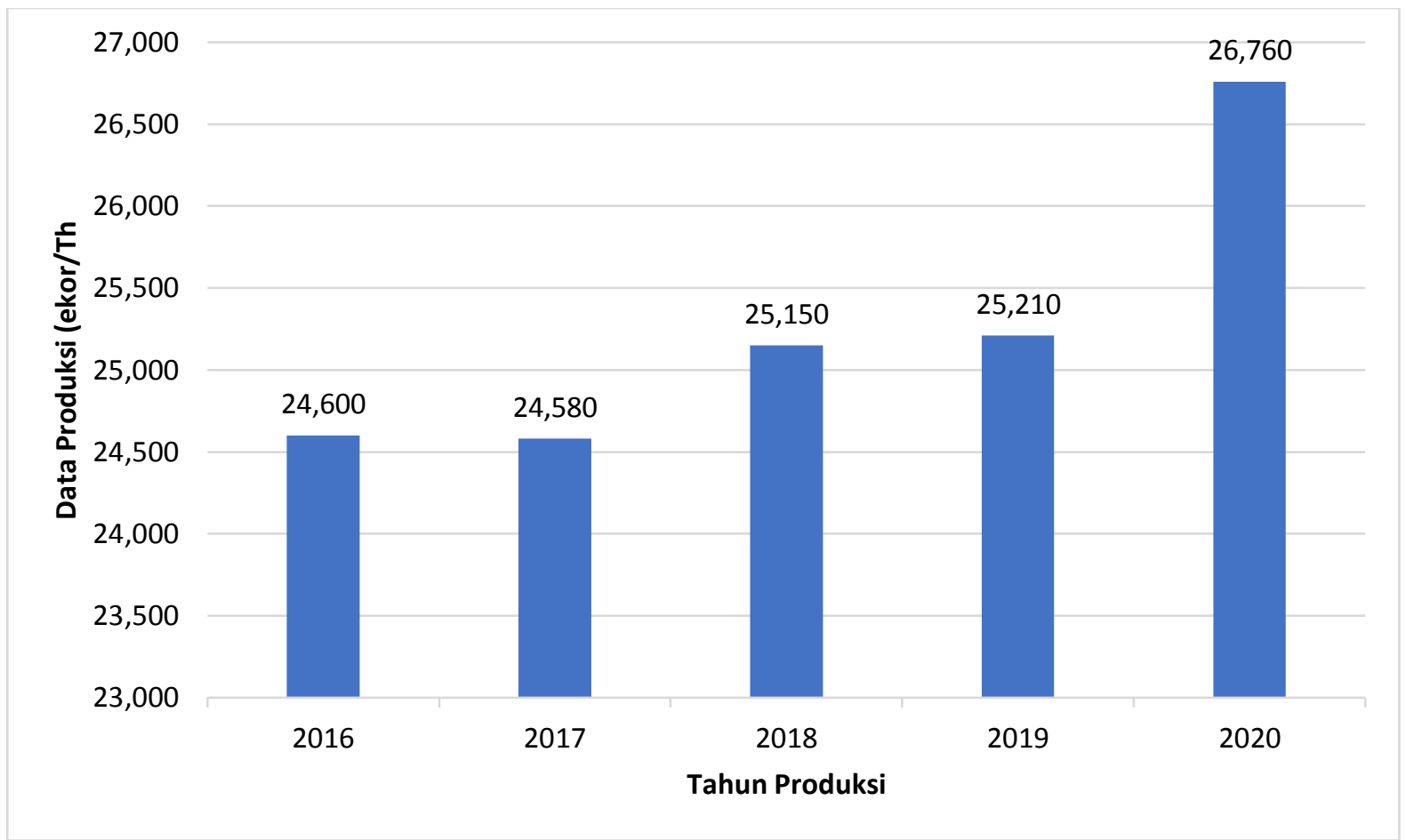

Gambar 4. Evaluasi Produksi Ikan

Hasil evaluasi menunjukan pelaksanaan program diterima dan dijalankan secara baik sehingga kapasitas dan waktu produksi dapat tercapai.

\section{KESIMPUAN DAN SARAN}

\section{Kesimpulan}

1. Pelaksanaan program pengabdian masyarakat oleh Tim Perikanan UMM menujukan hasil Mitra mampu meningkatkan sistem budidaya ikan secara secara intensif melalui penerapan CBIB, mitra mampu memproduksi pakan ikan mandiri berbasis bahan baku lokal diwilayah mitra diantaranya melalui pemanfaatan limbah ampas tahu, dan silase sebagai bahan pakan, serta mitra dapat menerapkan teknik pengelolaan atau manajemen kualitas air melalui penerapan probiotik.

2. Mitra mampu memenuhi kebutuhan pakan ikan sebanyak $50 \%$ dari total kebutuhan pakan ikan, melalui kegiatan produksi pakan ikan mandiri berbasis bahan baku local.

\section{Saran}

Mitra secara berkelanjutan menerapkan cara budidaya ikan yang baik (CBIB) untuk menjaga kapasitas dan target waktu produksi, dan dapat terus melakukan pengembangan usaha.

\section{DAFTAR PUSTAKA}

Direktorat Jenderal Perikanan Budidaya, 2017. Petunjuk Pelaksanaan Cara Budidaya Ikan yang Baik (CBIB). Kementrian Kelautan dan Perikanan Republik Indonesia. Jakarta. 
Sutarjo G A, Warkoyo. 2019. KKN PPM Pemberdayaan Masyarakat melalui Pengembangan dan Penguatan Kelompok Pembudidaya Ikan (Pokdakan) Air Tawar Desa Sepanjang Kecamatan Gondanglegi Kabupaten malang. Jurnal Dedikasi UMM. Vol 16, Mei 2019. Malang

Sutarjo G A, Sudibyo R A, 2019. Peningkatan Kapasitas Produksi Ikan Melalui Penerapan Manajemen Kualitas Air dan Probiotik di Kelompok Raja Oling Kecamatan Sukun Kota Malang. Juranl Abdi Insani Unram. Vol. 7 Nomor 1, April 2019. 